\title{
The Limit of Anemia Tolerance during Hyperoxic Ventilation with Pure Oxygen in Anesthetized Domestic Pigs
}
A. Pape ${ }^{a}$
M. Steche ${ }^{a}$
$M$
M. Wedela
F. Schwerdel ${ }^{a}$
C.F. Weber ${ }^{a}$
B. Zwissler ${ }^{\mathrm{c}}$
O. Habler ${ }^{\text {b }}$

a Department of Anesthesia, Intensive Care Medicine and Pain Therapy, University Hospital

Frankfurt, and ${ }^{b} \mathrm{Clinic}$ of Anesthesiology, Surgical Intensive Care Medicine and Pain

Management, Krankenhaus Nordwest, Frankfurt/Main, and ${ }^{\mathrm{C} C l i n i c}$ of Anesthesiology,

Ludwig Maximilians University Hospital, Munich, Germany

\section{Key Words}

Acute normovolemic anemia - Critical hemoglobin concentration · Hemodilution · Hyperoxic ventilation · Oxygen transport

\begin{abstract}
Background: During acellular replacement of an acute blood loss, hyperoxic ventilation (HV) increases the amount of $\mathrm{O}_{2}$ physically dissolved in the plasma and thereby improves $\mathrm{O}_{2}$ supply to the tissues. While this effect could be demonstrated for $\mathrm{HV}$ with inspiratory $\mathrm{O}_{2}$ fraction $\left(\mathrm{FiO}_{2}\right)$ 0.6, it was unclear whether $\mathrm{HV}$ with pure oxygen $\left(\mathrm{FiO}_{2} 1.0\right)$ would have an additional effect on the physiological limit of acute normovolemic anemia. Methods: Seven anesthetized domestic pigs were ventilated with $\mathrm{FiO}_{2} 1.0$ and subjected to an isovolemic hemodilution protocol. Blood was drawn and replaced by a $6 \%$ hydroxyethyl starch (HES) solution (130/0.4) until a sudden decrease of total body $\mathrm{O}_{2}$ consumption $\left(\mathrm{VO}_{2}\right)$ indicated the onset of $\mathrm{O}_{2}$ supply dependency (primary endpoint). The corresponding hemoglobin $(\mathrm{Hb})$ concentration was defined as 'critical $\mathrm{Hb}^{\prime}\left(\mathrm{Hb}_{\text {crit }}\right)$. Secondary endpoints were parameters of myocardial function, central hemodynamics, $\mathrm{O}_{2}$ transport and tissue oxygenation. Results: $\mathrm{HV}$ with $\mathrm{FiO}_{2} 1.0$ enabled a large blood-for-HES exchange (156 $\pm 28 \%$ of the circulating blood volume) until $\mathrm{Hb}_{\text {crit }}$ was met at $1.3 \pm 0.3 \mathrm{~g} / \mathrm{dl}$. After termination of the hemodilution protocol, the contribution of $\mathrm{O}_{2}$ physically dissolved in the plasma to $\mathrm{O}_{2}$ delivery and $\mathrm{VO}_{2}$ had significantly increased from $11.7 \pm 2$ to $44.2 \pm 9.7 \%$ and from $29.1 \pm 4.2$ to $66.2 \pm 11.7 \%$, respectively. However, at $\mathrm{Hb}_{\text {crit, }}$ cardiovascular performance was found to have severely deteriorated. Conclusion: $\mathrm{HV}$ with $\mathrm{FiO}_{2} 1.0$ maintains $\mathrm{O}_{2}$ supply to tissues during extensive blood-for-HES exchange. In acute situations, where profound anemia must be tolerated (e.g. bridging an acute blood loss until red blood cells become available for transfusion), $\mathrm{O}_{2}$ physically dissolved in the plasma becomes an essential source of oxygen. However, compromised cardiovascular performance might require additional treatment.


Pape et al.: The Limit of Anemia Tolerance during Hyperoxic Ventilation with Pure Oxygen in Anesthetized Domestic Pigs

\section{Introduction}

The initial treatment of an acute blood loss usually consists in the infusion of crystalloid and/or colloidal fluids. However, the restoration of normovolemia with acellular fluids leads to a dilution of the red cell mass remaining in the vasculature (acute normovolemic anemia). In this context, the term 'anemia tolerance' refers both to the patient's physiological condition to tolerate acute anemia and the physician's readiness to accept low hemoglobin $(\mathrm{Hb})$ values (e.g. during restrictive transfusion regimes) [1].

Although $\mathrm{O}_{2}$ transport capacity decreases progressively with hemodilution, tissue oxygenation can be sustained over a wide range of decreasing $\mathrm{Hb}$ concentrations [2]. First, acute normovolemic anemia is compensated by increases in cardiac output and arteriovenous $\mathrm{O}_{2}$ extraction $\left(\mathrm{O}_{2} \mathrm{ER}\right)$ [3] so that $\mathrm{O}_{2}$ delivery $\left(\mathrm{DO}_{2}\right)$ to the tissues and $\mathrm{O}_{2}$ consumption $\left(\mathrm{VO}_{2}\right)$ remain constant. Second, at physiologic $\mathrm{Hb}$ concentrations, $\mathrm{DO}_{2}$ exceeds $\mathrm{VO}_{2}$ by the factor 3-4 [4]. Therefore, $\mathrm{O}_{2}$ supply to the tissues is still sufficient to meet their $\mathrm{O}_{2}$ demand even when $\mathrm{DO}_{2}$ begins to decrease at lower $\mathrm{Hb}$ concentrations (supply independency of $\mathrm{VO}_{2}$; fig. 1).

When $\mathrm{DO}_{2}$ falls below the value of $\mathrm{VO}_{2}, \mathrm{O}_{2}$ metabolism becomes dependent on $\mathrm{DO}_{2}$ and $\mathrm{VO}_{2}$ starts to decline (supply dependency of $\mathrm{VO}_{2}[5,6]$ ). The $\mathrm{Hb}$ concentration corresponding to the sudden decrease in $\mathrm{VO}_{2}$ is called 'critical $\mathrm{Hb}^{\prime}\left(\mathrm{Hb}_{\text {crit }}\right)$ and reflects the individual limit of anemia tolerance [1].

Hyperoxic ventilation (HV) provides a simple but effective possibility to improve $\mathrm{O}_{2}$ supply to the tissues, when the number of circulating red blood cells becomes insufficient to meet total-body $\mathrm{O}_{2}$ demand. In a previous study, we could already demonstrate that the institution of $\mathrm{HV}$ with inspiratory $\mathrm{O}_{2}$ fraction $\left(\mathrm{FiO}_{2}\right) 0.6$ prior to induction of acute normovolemic anemia allowed for hemodilution to lower values of $\mathrm{Hb}_{\text {crit }}$ than did ventilation with ambient air [7]. However, the question remained open whether using pure oxygen could additionally increase anemia tolerance. We therefore hypothesized that $\mathrm{HV}$ with $\mathrm{FiO}_{2} 1.0$ allows for a more extensive hemodilution, even resulting in a lower value of $\mathrm{Hb}_{\text {crit }}$ than $\mathrm{HV}$ with $\mathrm{FiO}_{2}$ 0.6.

\section{Materials and Methods}

With the approval of the governmental review board (approval code V54-19c 20/15-91/30), experiments were performed in 7 healthy farm-bred pigs of either sex (body weight $29.8 \pm 3.7 \mathrm{~kg}$ ). All animals received good care in compliance with the Guide for the Care and Use of Laboratory Animals.

\section{Anesthesia and Ventilation}

Twelve hours before the experiments, the animals were denied food but had free access to water. After i.m. premedication with $10 \mathrm{mg} / \mathrm{kg}$ ketamine and $1 \mathrm{mg} / \mathrm{kg}$ midazolam, anesthesia was induced by i.v. injection of fentanyl ( $20 \mu \mathrm{g} / \mathrm{kg})$ and propofol $(1.5 \mathrm{mg} / \mathrm{kg})$ and maintained by continuous infusion of midazolam $(0.01$ $\mathrm{mg} / \mathrm{kg} / \mathrm{min})$, propofol $(0.16 \mathrm{mg} / \mathrm{kg} / \mathrm{min})$ and fentanyl $(0.8 \mu \mathrm{g} / \mathrm{kg} / \mathrm{min})$. To facilitate intubation, animals were paralyzed by a bolus injection of pancuronium $(0.2 \mathrm{mg} / \mathrm{kg})$. For adequate assessment of oxygen tension $\left(\mathrm{tpO}_{2}\right)$ on the surface of a skeletal muscle (see below), neuromuscular blockade (NMB) was maintained by continuous infusion of pancuronium $(0.12 \mathrm{mg} / \mathrm{min}$ ). Estimated fluid losses (particularly including insensible perspiration owing to the open-chest model, see below) were replaced by a balanced electrolyte solution $(0.25 \mathrm{ml} / \mathrm{kg} / \mathrm{min})$. All trade names of anesthetics and infusion fluids used are listed in the Appendix.

After orotracheal intubation, animals were ventilated using the CMV mode (controlled mandatory ventilation; 12 cycles/min, PEEP $5 \mathrm{~cm} \mathrm{H}_{2} \mathrm{O}$; Vela Ventilator, Viasys Healthcare, Höchberg, Germany). Based on repeated blood gas analyses, tidal volume was adjusted to provide arterial normocapnia and was then maintained throughout the entire protocol. Until the end of surgical preparation, all animals were ventilated with ambient air. 
Pape et al.: The Limit of Anemia Tolerance during Hyperoxic Ventilation with Pure Oxygen in Anesthetized Domestic Pigs

Fig. 1. Relationship between $\mathrm{VO}_{2}$ and $\mathrm{DO}_{2}$. Physiologically, $\mathrm{DO}_{2}$ amounts to 3- to 4-fold of $\mathrm{VO}_{2}$. Over a long period, $\mathrm{VO}_{2}$ remains independent of $\mathrm{DO}_{2}$ despite the anemia-related decrease of $\mathrm{DO}_{2}$. When $\mathrm{Hb}_{\text {crit }}$ is reached, $\mathrm{DO}_{2}$ falls short of the actual $\mathrm{O}_{2}$ demand and $\mathrm{VO}_{2}$ begins to decrease (onset of $\mathrm{O}_{2}$ supply dependency of $\mathrm{VO}_{2}$ ).

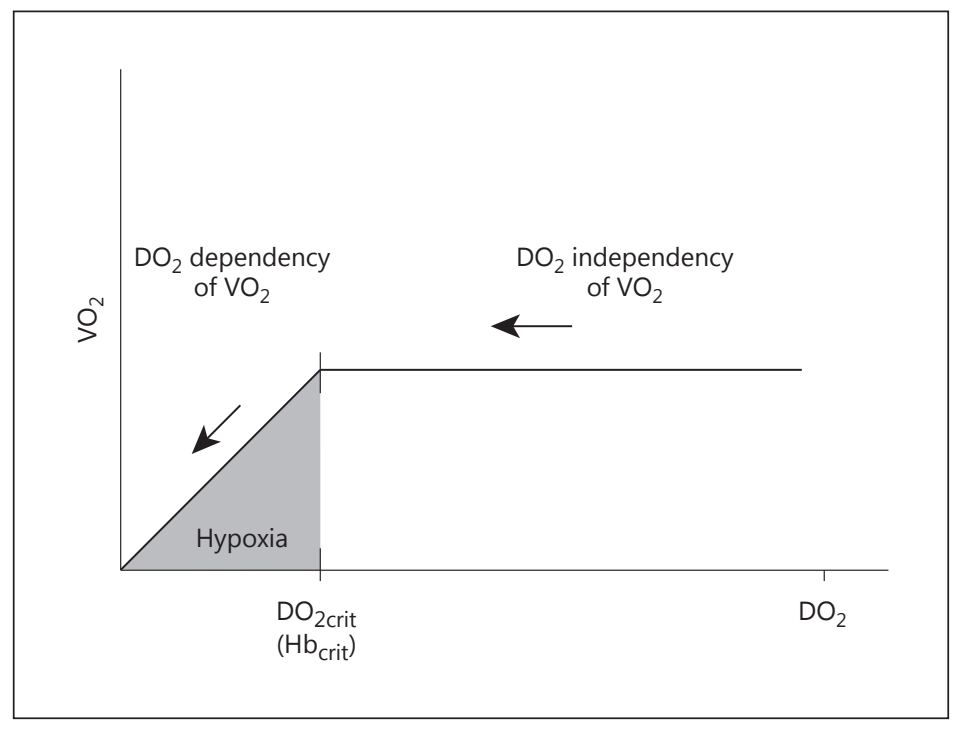

\section{Instrumentation and Monitoring}

All animals were placed in supine position. A 5-lead electrocardiogram (II,V5) was installed for detection of arrhythmias and ST segment changes. Animals were instrumented with 2 electronic tip manometer catheters (PC 370, Millar Instruments, Houston, Tex., USA) placed in the abdominal part of the aorta and in the left ventricle. A double-lumen catheter (Arrow, Reading, Pa., USA) was inserted into the superior vena cava, and a Swan-Ganz catheter (right ventricular ejection fraction/volumetric catheter, Baxter, Irvine, Calif., USA) was floated into a branch of the pulmonary artery. After midline sternotomy and opening of the pericardium, an ultrasonic flow probe (diameter $14 \mathrm{~mm}$; Transonic Systems, Ithaca, N.Y., USA) was placed around the root of the aorta for continuous measurement of cardiac output. The left anterior descending coronary artery (LAD) was dissected free from surrounding tissue, and an additional ultrasonic flow probe (diameter $2 \mathrm{~mm}$; Transonic Systems) was implanted for assessment of coronary blood flow. For withdrawal of coronary venous blood samples, the anterior interventricular vein was cannulated with an 18-gauge Teflon catheter (Leader Cath, Vygon, Ecouen, France). A large-bore hemodialysis catheter and a 7-French introducer sheath (both by Arrow) were inserted into the left femoral vein and into the right femoral artery for withdrawal of blood and isovolemic infusion of hydroxyethyl starch (HES), respectively. Via a mini-laparotomy, a Foley catheter (Rüsch, Kernen, Germany) was inserted into the urinary bladder. An area of $3 \times 5 \mathrm{~cm}$ of the anterior rectus abdominis muscle was dissected free from surrounding tissue for measurement of tpO $\mathrm{O}_{2}$. Body temperature was kept constant using a warming pad and a warming lamp.

\section{Experimental Protocol}

After completion of surgical preparation and installation of the different measuring devices, $\mathrm{FiO}_{2}$ was increased to 1.0 and a new calibration of the Oxycon Pro ${ }^{\mathrm{TM}}$ device (Viasys Healthcare) was performed with pure oxygen. Subsequently, a 60-min stabilization period was allowed to elapse to achieve stable baseline conditions.

The baseline data set was recorded, and subsequently, acute normovolemic anemia was induced by simultaneous exchange of blood for $6 \%$ tetrastarch (HES 130/0.4, exchange rate $1 \mathrm{ml} / \mathrm{kg} / \mathrm{min}$ ). The target parameter was the animal's individual $\mathrm{Hb}_{\text {crit }}$. When this target was met, a second set of data was collected. Subsequently, animals were killed by intracardial injection of saturated potassium solution.

Determination of $\mathrm{Hb} b_{\text {crit }}$

$\mathrm{Hb}_{\text {crit }}$ is the correlate of the critical limitation of $\mathrm{DO}_{2}$ and marks the onset of total body $\mathrm{O}_{2}$ supply dependency (fig. 1). The corresponding decrease of $\mathrm{VO}_{2}$ was detected in an automated and investigator-independent manner: $\mathrm{VO}_{2}$ was measured with an ergospirometer (Oxycon Pro). $\mathrm{VO}_{2}$ values were recorded and computed with a specific software (DeltaCrit System, DCS) [8]. During the stabilization period, DCS includes $\mathrm{VO}_{2}$ values into an online regression analysis and calculates mean and third standard deviation (SD). During 
Pape et al.: The Limit of Anemia Tolerance during Hyperoxic Ventilation with Pure Oxygen in Anesthetized Domestic Pigs

Fig. 2. Typical example of $\mathrm{VO}_{2}$ recording in the course of the experimental protocol. A linear regression analysis including the calculation of SD was performed with $\mathrm{VO}_{2}$ values collected during the 60-min stabilization period. During the subsequent hemodilution protocol, a critical limitation of $\mathrm{DO}_{2}$ was assumed when 3 consecutive $\mathrm{VO}_{2}$ values fell below the lower $3 \sigma$ range.

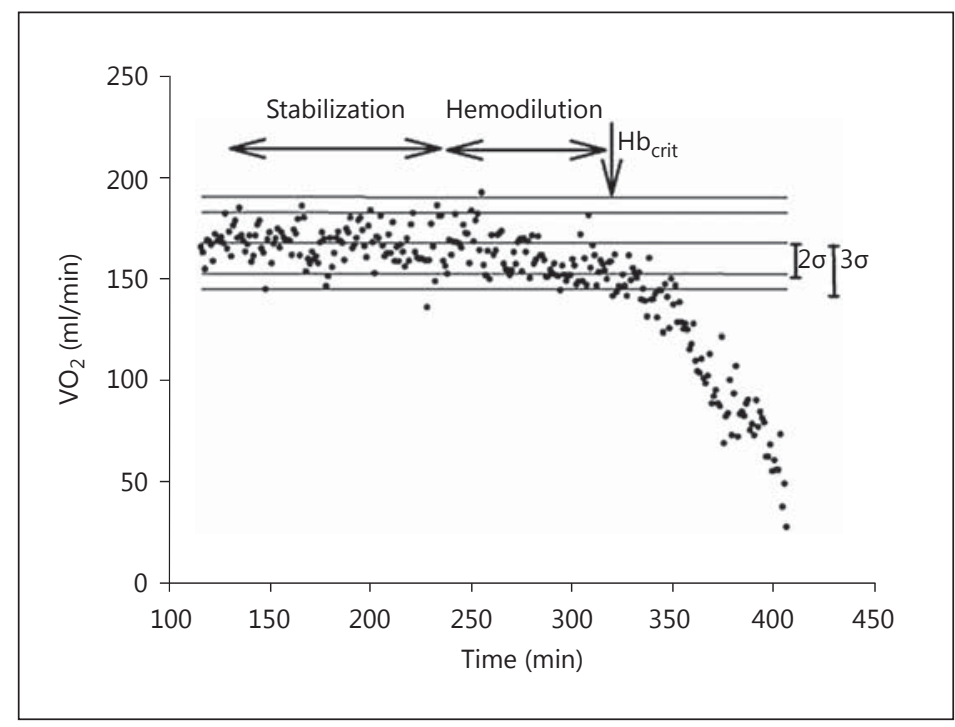

the subsequent hemodilution period, every $\mathrm{VO}_{2}$ value is compared to the mean value predicted by DCS. When 3 subsequent $\mathrm{VO}_{2}$ values are outside the predefined range ( $3 \times \mathrm{SD}$ of regression line), a significant decrease of $\mathrm{VO}_{2}$ is assumed and indicated by a visual and acoustic computer alert [8]. A typical $\mathrm{VO}_{2}$ recording is depicted in figure 2 .

\section{Measurements}

Blood volume was determined at baseline and at the individual $\mathrm{Hb}_{\text {crit }}\left(\mathrm{Hb}_{\text {crit }}-1.0\right)$ using the 'whole-blood' method of the indocyanine green indicator dilution technique, which has already been described in detail elsewhere [9]. The pressure transducers and flowmeters of the hemodynamic measurement devices were connected with a multichannel recorder (Hugo Sachs, March-Hugstetten, Germany) and measurement readings were recorded with a personal computer. The indices of cardiac output (cardiac index, $\mathrm{CI}$ ) and systemic vascular resistance index (SVRI) as well as pulmonary vascular resistance index (PVRI) were calculated relative to body surface area (see Appendix).

Arterial, mixed venous and coronary venous blood samples were drawn at baseline and at $\mathrm{Hb}_{\text {crit }}-1.0$ for blood gas analysis (ABL 300, Radiometer, Copenhagen, Denmark) and assessment of Hb concentration (682 CO-Oximeter, Instrumentation Laboratory, Lexington, Mass., USA).

During the hemodilution period, arterial and mixed venous blood samples were drawn after every 200 $\mathrm{ml}$ of blood exchange. Hemodynamic parameters were registered continuously with the laboratory setup.

For comparison with the results of our previous study, 2 additional data sets corresponding to $\mathrm{Hb} \sim 2.4$ $\mathrm{g} / \mathrm{dl}\left(\mathrm{Hb}_{\text {crit }}-0.21\right.$, i.e. $\mathrm{Hb}_{\text {crit }}$ in animals ventilated with $\left.\mathrm{FiO}_{2} 0.21\right)$ and $\mathrm{Hb} \sim 1.6 \mathrm{~g} / \mathrm{dl}\left(\mathrm{Hb}_{\text {crit }}-0.6\right.$, i.e. $\mathrm{Hb}_{\text {crit }}$ in animals ventilated with $\mathrm{FiO}_{2}$ 0.6) were retrospectively read out from the continuous recordings.

$\mathrm{tpO}_{2}$ on the surface of the skeletal muscle was determined at baseline and at $\mathrm{Hb}_{\text {crit }}-1.0$ using 2 multiwire platinum surface electrodes (MDO-Electrode, Eschweiler, Kiel, Germany) connected with a microprocessor system (Ingenieurbüro Mussler, Aachen, Germany). After equilibration with the tissue surface, this method enables exact assessment of $\mathrm{tpO}_{2}$ [10]. With each measurement, 240 individual $\mathrm{tpO}_{2}$ values were recorded; the location of the electrodes on the muscle surface was changed 3-5 times each.

\section{Statistics}

Statistical analysis was performed using the SAS 9.2 software package (SAS Institute, Cary, N.C., USA). All data are presented as means \pm SD. Data distribution was assessed using Shapiro-Wilk test.

In case of normal distribution, time effects on the different variables were tested by repeated analysis of variance (ANOVA). Post hoc analysis of differences detected with ANOVA was performed with the StudentNewman-Keuls test. In case of nonnormal distribution, time effects on the parameters were tested by analysis of variance on ranks (rANOVA). Post hoc analysis of differences detected with rANOVA was performed with Tukey's test. 
Fig. 3. Hb concentrations at baseline and at $\mathrm{Hb}_{\text {crit. }}$ Beginning with a Hb concentration of $7.7 \pm 0.5 \mathrm{~g} / \mathrm{dl}$ at baseline, $\mathrm{Hb}_{\text {crit }}$ was met at $1.3 \pm$ $0.3 \mathrm{~g} / \mathrm{dl}$.

Pape et al.: The Limit of Anemia Tolerance during Hyperoxic Ventilation with Pure Oxygen in Anesthetized Domestic Pigs

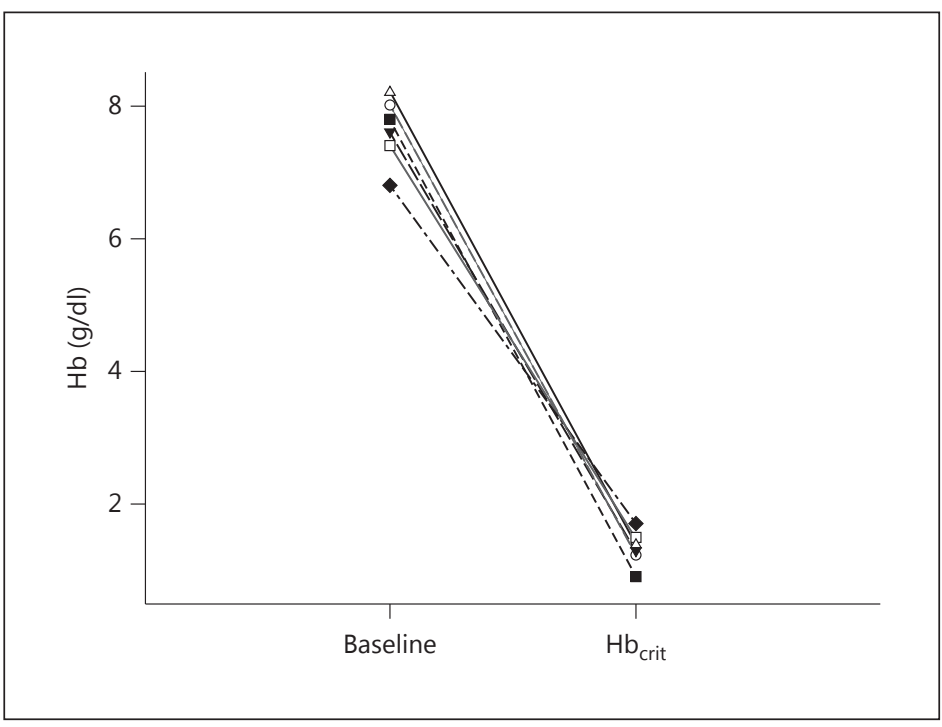

Statistical analysis of the parameter ' $\mathrm{tpO}_{2}$ ' was performed by a paired $\mathrm{t}$ test analysis of the medians of the single $\mathrm{tpO}_{2}$ values obtained per observation (see above).

For all parameters, statistical significance was accepted at $\mathrm{p}<0.05$.

\section{Results}

Primary Endpoint: $H b_{\text {crit }}$

Hemodilution to $\mathrm{Hb}_{\text {crit }}-1.0$ required the exchange of 3,749 $\pm 640 \mathrm{ml}$ of blood for HES, corresponding with an exchange of $156 \pm 28 \%$ of the circulating blood volume. Beginning with a $\mathrm{Hb}$ concentration of $7.7 \pm 0.5 \mathrm{~g} / \mathrm{dl}$ at baseline, $\mathrm{Hb}_{\text {crit }}-1.0$ was met at $1.3 \pm 0.3 \mathrm{~g} / \mathrm{dl}$ (fig. 3).

Secondary Endpoints: Hemodynamic and $\mathrm{O}_{2}$-Derived Parameters

Table 1 displays secondary endpoint parameters at baseline, after hemodilution to $\mathrm{Hb}$ $2.4 \mathrm{~g} / \mathrm{dl}$ (i.e. $\mathrm{Hb}_{\text {crit }}-0.21$ ) and $\mathrm{Hb} 1.6 \mathrm{~g} / \mathrm{dl}$ (i.e. $\mathrm{Hb}_{\text {crit }}-0.6$ ), and finally at the critical Hb concentration $\left(\mathrm{Hb}_{\text {crit }}-1.0\right)$.

\section{Hemodynamics and Myocardial Function}

During hemodilution to $\mathrm{Hb} 2.4 \mathrm{~g} / \mathrm{dl}$, heart rate (HR) increased by $27 \%$ and increased by a further $36 \%$ during hemodilution to $\mathrm{Hb} 1.5 \mathrm{~g} / \mathrm{dl}$. At $\mathrm{Hb}_{\text {crit }}-1.0$, HR decreased to baseline level. While mean pulmonary arterial pressure remained almost unchanged during the hemodilution protocol, mean arterial pressure decreased continuously and was significantly beyond baseline level at $\mathrm{Hb}_{\text {crit. }}$ Consistently, $\mathrm{CI}$ increased initially, while SVRI decreased by $51 \%$ during hemodilution to $\mathrm{Hb} 2.4 \mathrm{~g} / \mathrm{dl}$, by $36 \%$ during hemodilution to $\mathrm{Hb} 1.5 \mathrm{~g} / \mathrm{dl}$ and by a further $37 \%$ during the final hemodilution step.

Left ventricular (LV) systolic contractility reflected by the maximal slope of LV pressure increase $\left(\mathrm{dp} / \mathrm{dt}_{\max }\right)$ increased at the beginning of the hemodilution protocol, but decreased under baseline level at $\mathrm{Hb}_{\text {crit }}-1$.0. Likewise, $\mathrm{LV}$ diastolic function represented by the maximum $\mathrm{LV}$ pressure decrease $\left(\mathrm{dp} / \mathrm{dt}_{\min }\right)$ had severely deteriorated at $\mathrm{Hb}_{\text {crit }}-1.0$. 
Pape et al.: The Limit of Anemia Tolerance during Hyperoxic Ventilation with Pure Oxygen in Anesthetized Domestic Pigs

Table 1. Hemodynamic and $\mathrm{O}_{2}$-derived parameters assessed in animals ventilated with $\mathrm{FiO}_{2} 1.0$

\begin{tabular}{|c|c|c|c|c|}
\hline Parameter & Baseline & $\mathrm{Hb}_{\text {crit }}-0.21$ & $\mathrm{Hb}_{\text {crit }^{-}}-0.6$ & $\mathrm{Hb}_{\text {crit }}-1.0$ \\
\hline $\mathrm{Hb}, \mathrm{g} / \mathrm{dl}$ & $7.7 \pm 0.5$ & $2.4 \pm 0.5^{*}$ & $1.6 \pm 0.4^{*, \S}$ & $1.3 \pm 0.3^{*, \S}$ \\
\hline BVI, $\mathrm{m} / \mathrm{m}^{2}$ & $81 \pm 8$ & n.d. & n.d. & $79 \pm 38$ \\
\hline $\mathrm{HR}, \mathrm{l} / \mathrm{min}$ & $74 \pm 9$ & $94 \pm 17^{*}$ & $101 \pm 20^{*}$ & $85 \pm 16$ \\
\hline MAP, mm Hg & $91 \pm 18$ & $78 \pm 31$ & $57 \pm 28^{*}, \S$ & $34 \pm 6^{*, \S, \#}$ \\
\hline MPAP, mm Hg & $23 \pm 3$ & $25 \pm 4$ & $23 \pm 3$ & $21 \pm 4^{\S}$ \\
\hline $\mathrm{CI}, \mathrm{l} / \mathrm{min} / \mathrm{m}^{2}$ & $3.3 \pm 0.3$ & $4.7 \pm 0.4^{*}$ & $4.6 \pm 1.0^{*}$ & $3.7 \pm 1.2$ \\
\hline $\mathrm{SVI}, \mathrm{ml} / \mathrm{m}^{2}$ & $45 \pm 5$ & $51 \pm 9$ & $46 \pm 9$ & $44 \pm 9$ \\
\hline SVRI, dyn $\bullet \mathrm{s} / \mathrm{cm}^{5} / \mathrm{m}^{2}$ & $2,352 \pm 556$ & $1,172 \pm 464$ & $755 \pm 345^{*}$ & $482 \pm 110^{*, \S}$ \\
\hline PVRI, dyn $\bullet$ s $/ \mathrm{cm}^{5} / \mathrm{m}^{2}$ & $304 \pm 111$ & $163 \pm 158$ & $159 \pm 211$ & $164 \pm 224$ \\
\hline LVP, mm Hg & $107 \pm 20$ & $98 \pm 29$ & $78 \pm 24^{*}$ & $59 \pm 6^{*, \S}$ \\
\hline LVEDP, mm Hg & $10 \pm 2$ & $16 \pm 5$ & $15 \pm 9$ & $14 \pm 5$ \\
\hline $\mathrm{dp} / \mathrm{dt}_{\max }, \mathrm{mm} \mathrm{Hg} / \mathrm{s}$ & $2,258 \pm 796$ & $2,850 \pm 2,471$ & $2,638 \pm 2,607$ & $1,178 \pm 462$ \\
\hline $\mathrm{dp} / \mathrm{dt}_{\mathrm{min}}, \mathrm{mm} \mathrm{Hg} / \mathrm{s}$ & $-3,372 \pm 835$ & $-3,003 \pm 1,821$ & $-2,265 \pm 2,587$ & $-863 \pm 350 *$ \\
\hline $\mathrm{VO}_{2} \mathrm{I}, \mathrm{ml} / \mathrm{m}^{2} / \mathrm{min}$ & $154 \pm 16$ & $135 \pm 16$ & $131 \pm 18$ & $140 \pm 15$ \\
\hline $\mathrm{DO}_{2} \mathrm{I}, \mathrm{ml} / \mathrm{m}^{2} / \mathrm{min}$ & $374 \pm 43$ & $233 \pm 28^{*}$ & $148 \pm 27^{*, \S}$ & 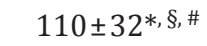 \\
\hline $\mathrm{CaO}_{2}, \mathrm{ml} / \mathrm{dl}$ & $11.4 \pm 0.7$ & $4.9 \pm 0.5^{*}$ & $3.2 \pm 0.2^{*, \S}$ & $3.0 \pm 0.2^{*, \S}$ \\
\hline $\mathrm{O}_{2} \mathrm{ER}, \%$ & $36 \pm 3$ & $45 \pm 4 *$ & $55 \pm 1 *, \S$ & $60 \pm 4^{*, \S, \#}$ \\
\hline $\mathrm{paO}_{2}, \mathrm{~mm} \mathrm{Hg}$ & $432 \pm 78$ & $397 \pm 41$ & $389 \pm 50$ & $418 \pm 64$ \\
\hline $\mathrm{pvO}_{2}, \mathrm{~mm} \mathrm{Hg}$ & $44 \pm 2$ & $42 \pm 4$ & $40 \pm 3$ & $38 \pm 3^{*}$ \\
\hline $\mathrm{pH}$ & $7.45 \pm 0.02$ & $7.41 \pm 0.07$ & $7.37 \pm 0.07$ & $7.35 \pm 0.07^{*}$ \\
\hline $\mathrm{paCO}_{2}, \mathrm{~mm} \mathrm{Hg}$ & $39 \pm 4$ & $40 \pm 5$ & $38 \pm 4$ & $38 \pm 5$ \\
\hline $\mathrm{HCO}_{3}, \mathrm{~mm} \mathrm{Hg}$ & $26 \pm 2$ & $24 \pm 2^{*}$ & $21 \pm 2^{*, \S}$ & $21 \pm 1^{*, \S}$ \\
\hline $\mathrm{BE}, \mathrm{mmol} / \mathrm{l}$ & $3.3 \pm 1.5$ & $0.3 \pm 3.0$ & $2.9 \pm 2.7^{*}$ & $3.9 \pm 2.5^{*, \S}$ \\
\hline Lactate, $\mathrm{mmol} / \mathrm{l}$ & $0.9 \pm 0.2$ & $0.8 \pm 0.2$ & $1.7 \pm 0.8^{*, \S}$ & $2.2 \pm 0.9^{*, \S}$ \\
\hline $\mathrm{CPP}, \mathrm{mm} \mathrm{Hg}$ & $59 \pm 21$ & $41 \pm 29 *$ & $23 \pm 24^{*}, \S$ & $9 \pm 7^{*, \S}$ \\
\hline LAD flow, $\mathrm{ml} / \mathrm{min}$ & $44 \pm 13$ & $123 \pm 44^{*}$ & $120 \pm 49^{*}$ & $78 \pm 27 *, \S$, \# \\
\hline $\mathrm{mDO}_{2}, \mathrm{ml} / \mathrm{min}$ & $509 \pm 164$ & $626 \pm 267$ & $382 \pm 150^{\S}$ & $230 \pm 76^{*, \S}$ \\
\hline $\mathrm{mVO}_{2}, \mathrm{ml} / \mathrm{min}$ & $367 \pm 119$ & n.d. & n.d. & $153 \pm 64^{*}$ \\
\hline $\mathrm{mO}_{2} \mathrm{ER}, \%$ & $72 \pm 6$ & n.d. & n.d. & $66 \pm 16$ \\
\hline cv lactate, $\mathrm{mmol} / \mathrm{l}$ & $0.6 \pm 0.2$ & n.d. & n.d. & $2.2 \pm 0.8$ \\
\hline
\end{tabular}

$\mathrm{BVI}=$ Blood volume indexed to body surface area; MAP = mean aortic pressure; MPAP = mean pulmonary arterial pressure; SVI = stroke volume index; LVP = left ventricular pressure; LVEDP = left ventricular end-diastolic pressure; $\mathrm{VO}_{2} \mathrm{I}$ and $\mathrm{DO}_{2} \mathrm{I}=$ indices of $\mathrm{VO}_{2}$ and $\mathrm{DO}_{2} ; \mathrm{paO}_{2}$ and $\mathrm{pvO}_{2}=$ arterial and mixed venous $\mathrm{O}_{2}$ partial pressures; $\mathrm{paCO}_{2}=$ arterial carbon dioxide partial pressure; $\mathrm{HCO}_{3}=$ arterial bicarbonate concentration; $\mathrm{BE}=$ base excess; lactate = lactate concentration; $\mathrm{mDO}_{2}$ and $\mathrm{mVO}_{2}=\mathrm{DO}_{2}$ and $\mathrm{VO}_{2}$ of LAD-supplied myocardium; $\mathrm{mO}_{2} \mathrm{ER}=$ myocardial $\mathrm{O}_{2} \mathrm{ER} ; \mathrm{cv}$ lactate = coronary venous lactate concentration.

${ }^{*} \mathrm{p}<0.05$ vs. baseline; ${ }^{\S} \mathrm{p}<0.05$ vs. $\mathrm{Hb}_{\text {crit }}-0.21 ;{ }^{\#} \mathrm{p}<0.05$ vs. $\mathrm{Hb}_{\text {crit }}-0.6$.

\section{$\mathrm{O}_{2}$ Transport and Tissue Oxygenation}

Proportionally with the decrease in $\mathrm{Hb}$ concentration and arterial $\mathrm{O}_{2}$ content $\left(\mathrm{CaO}_{2}\right), \mathrm{DO}_{2}$ index decreased by $38 \%$ (hemodilution to $\mathrm{Hb} 2.4 \mathrm{~g} / \mathrm{dl}$ ), $37 \%$ ( $\mathrm{Hb} 1.5 \mathrm{~g} / \mathrm{dl}$ ) and $36 \%\left(\mathrm{Hb}_{\text {crit }^{-}}\right.$ 1.0). As a compensation of acute anemia, arteriovenous $\mathrm{O}_{2}$ ER increased with every hemodilution step, which was accompanied by a slight but constant decrease of mixed venous $\mathrm{O}_{2}$ partial pressure $\left(\mathrm{pvO}_{2}\right)$.

Hemodilution markedly decreased the contribution of $\mathrm{Hb}$-transported $\mathrm{O}_{2}$ to $\mathrm{DO}_{2}$ and $\mathrm{VO}_{2}$. Simultaneously, the contribution of physically dissolved $\mathrm{O}_{2}$ to $\mathrm{DO}_{2}$ increased from 11.7 $\pm 2 \%$ (baseline) to $44.2 \pm 9.7 \%\left(\mathrm{Hb}_{\text {crit }} ; \mathrm{p}<0.05\right)$ and its contribution to $\mathrm{VO}_{2}$ increased from $29.1 \pm 4.3$ to $66.2 \pm 11.7 \%$ (p < 0.05; fig. $4 \mathrm{a}, \mathrm{b}$ ) .

Despite the utilization of physically dissolved $\mathrm{O}_{2}$, lactate concentration was elevated above baseline level at $\mathrm{Hb} 1.5 \mathrm{~g} / \mathrm{dl}(\mathrm{p}<0.05)$ and further increased after continuation of 
Pape et al.: The Limit of Anemia Tolerance during Hyperoxic Ventilation with Pure
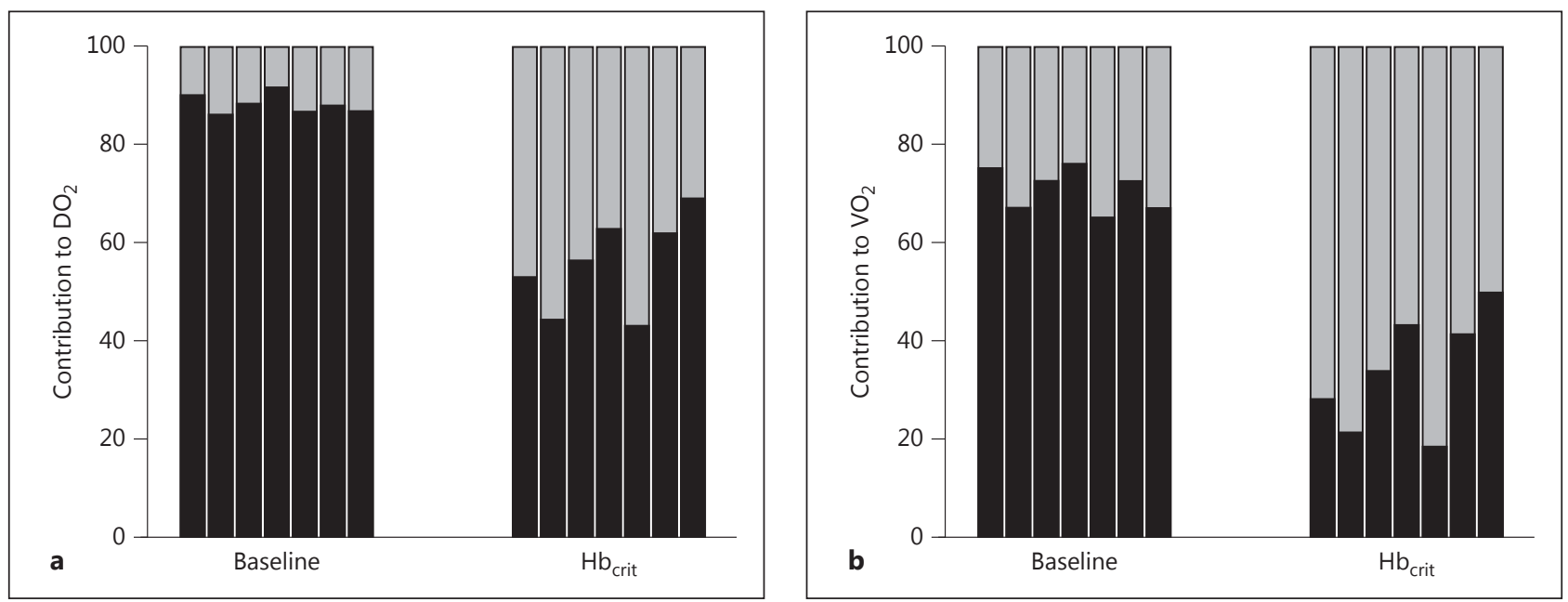

Fig. 4. a Contribution of Hb-transported $\mathrm{O}_{2}$ (black) and physically dissolved $\mathrm{O}_{2}$ (gray) to $\mathrm{DO}_{2}$ at baseline and at $\mathrm{Hb}_{\text {crit. }}$ Each bar represents 1 animal. During hemodilution, the contribution of physically dissolved $\mathrm{O}_{2}$ increased from $11.7 \pm 2$ to $44.2 \pm 9.7 \%$ ( $\mathrm{p}<0.05$ ). $\mathbf{b}$ Contribution of Hb-transported $\mathrm{O}_{2}$ (black) and physically dissolved $\mathrm{O}_{2}$ (gray) to $\mathrm{VO}_{2}$ at baseline and at $\mathrm{Hb}_{\text {crit }}$. Each bar represents 1 animal. During hemodilution, the contribution of physically dissolved $\mathrm{O}_{2}$ to $\mathrm{VO}_{2}$ increased from $29.1 \pm 4.3$ to $66.2 \pm 11.7 \%(\mathrm{p}<0.05)$.

Fig. 5. Sum histograms of all tpO $\mathrm{O}_{2}$ values obtained on the surface of a skeletal muscle at baseline (bottom) and at $\mathrm{Hb}_{\text {crit }}$ (top). $\mathrm{x}$-axis: $\mathrm{tpO}_{2}$ values are displayed in classes of $5 \mathrm{~mm} \mathrm{Hg}$. $y$-axis: relative frequency of $\mathrm{tpO}_{2}$ values. At $\mathrm{Hb}_{\text {crit }}$ the histogram is left shifted, indicating that the relative frequency of low $\mathrm{tpO}_{2}$ values had increased: the median of the $\mathrm{tpO}_{2}$ values decreased from $33.8 \pm 12.1$ to $8 \pm 6$ $\mathrm{mm} \mathrm{Hg}(\mathrm{p}<0.05)$ and the rate of hypoxic values increased from $9 \pm$ 4 to $64 \pm 33 \%(\mathrm{p}<0.05)$.

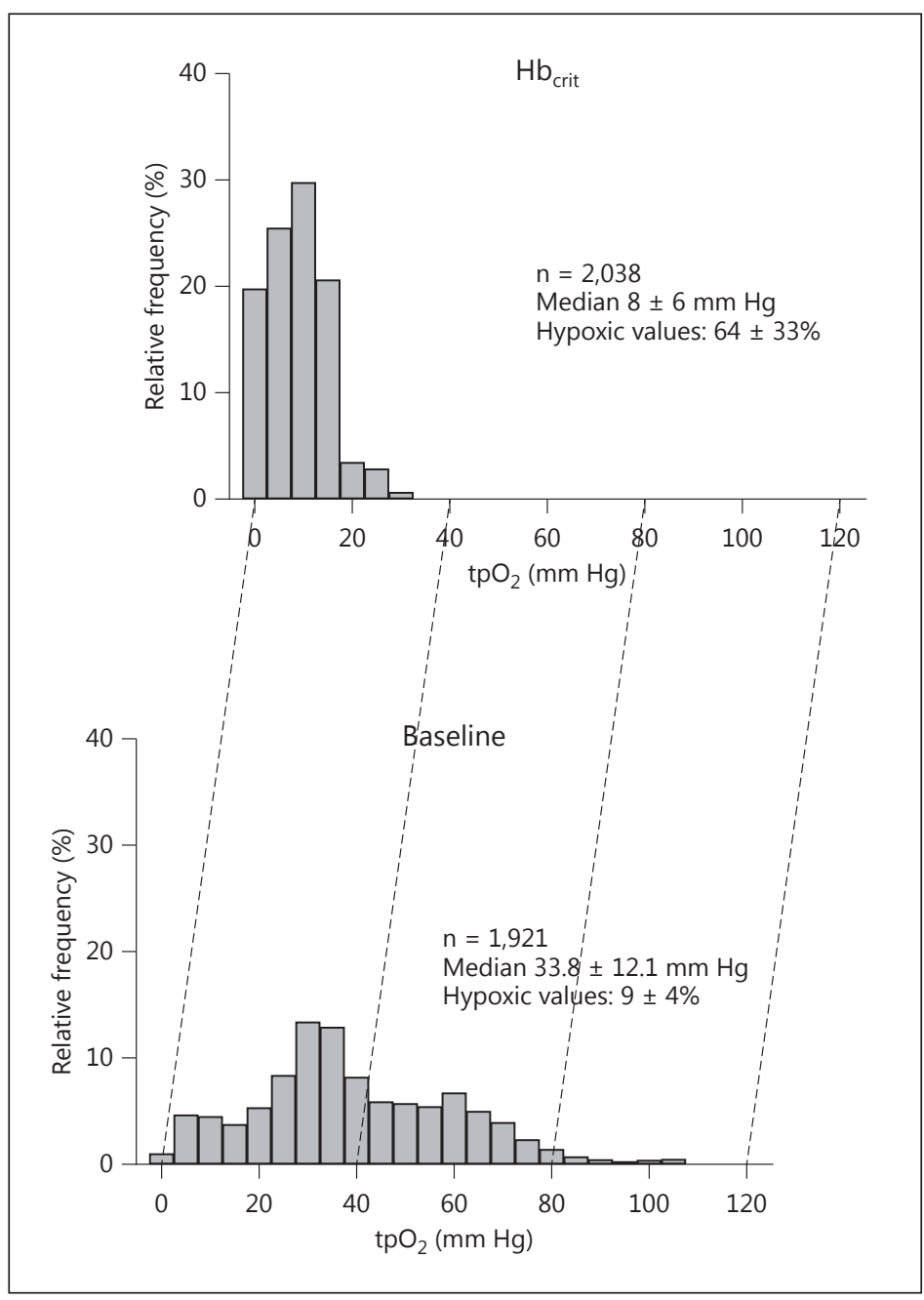


Pape et al.: The Limit of Anemia Tolerance during Hyperoxic Ventilation with Pure

Oxygen in Anesthetized Domestic Pigs

hemodilution to $\mathrm{Hb}_{\text {crit }}-1.0$. Consistently, base excess decreased by $90 \%$ during the first 2 hemodilution steps and by a further $34 \%$ during hemodilution from $1.5 \mathrm{~g} / \mathrm{dl}$ to $\mathrm{Hb}_{\text {crit }}$.

Manifest tissue hypoxia on the surface of the skeletal muscle was indicated by the typical left shift of tpO $\mathrm{O}_{2}$ sum histograms (fig. 5). The median decreased from $33.8 \pm 12.1$ to $8 \pm 6 \mathrm{~mm}$ $\mathrm{Hg}(\mathrm{p}<0.05)$ and the fraction of hypoxic values increased from $9 \pm 4$ to $64 \pm 33 \%(\mathrm{p}<0.05)$.

\section{Myocardial Perfusion and Oxygenation}

To compensate for increased myocardial $\mathrm{O}_{2}$ demand, coronary blood flow in the LAD increased initially by $279 \%$ (hemodilution to $\mathrm{Hb} 2.4 \mathrm{~g} / \mathrm{dl}$ ) and had a tendency to decrease during hemodilution from $\mathrm{Hb} 1.5 \mathrm{~g} / \mathrm{dl}$ to $\mathrm{Hb}_{\text {crit }}-1.0$.

However, during the entire hemodilution protocol, LAD flow remained increased. Consistently with the decrease of SVRI, coronary perfusion pressure (CPP) decreased continuously beyond baseline level. While $\mathrm{DO}_{2}$ to the LAD-supplied myocardium $\left(\mathrm{mDO}_{2}\right)$ decreased continuously, myocardial $\mathrm{O}_{2} \mathrm{ER}$ and $\mathrm{VO}_{2}$ remained almost unaltered. However, coronary venous lactate concentration was significantly increased at $\mathrm{Hb}_{\text {crit }}-1.0$, indicating compromised myocardial lactate extraction and aerobic capacity.

\section{Discussion}

The main result of the present study is that $\mathrm{HV}$ with $\mathrm{FiO}_{2} 1.0$ only provided a marginal increase of anemia tolerance as compared to animals ventilated with $\mathrm{FiO}_{2} 0.6$ in our previous study [7]. This is indicated by a slightly lower value of $\mathrm{Hb}_{\text {crit }}(1.3 \pm 0.3 \mathrm{vs} .1 .6 \pm 0.4 \mathrm{~g} / \mathrm{dl})$ and a higher volume of blood exchanged for HES $(3,749 \pm 640$ vs. 2,634 $\pm 407 \mathrm{ml})$.

Regarding secondary end points (table 2), animals ventilated with pure oxygen appeared slightly superior to animals ventilated with $\mathrm{FiO}_{2} 0.6$ regarding the following criteria: first, they presented less tachycardiac and less hypotensive at $\mathrm{Hb}_{\text {crit }}-0.21$. However, at their individual $\mathrm{Hb}_{\text {crit, }}$ cardiovascular performance was equally impaired. Second, the increase of lactate appeared attenuated and $\mathrm{pvO}_{2}$ tended to be higher at any time point. Third, at $\mathrm{Hb}_{\text {crit }}{ }^{-}$ 0.6 , myocardial perfusion appeared less compromised.

Proportionally with $\mathrm{FiO}_{2}, \mathrm{HV}$ increases the amount of $\mathrm{O}_{2}$ physically dissolved in the plasma. This effect gains importance in profound anemia, as the contribution of red blood cells to $\mathrm{O}_{2}$ transport is declining and the significance of the plasma compartment as an $\mathrm{O}_{2}$ reservoir is increasing. At the site of microcirculation, physically dissolved $\mathrm{O}_{2}$ is utilized more readily than $\mathrm{Hb}$-bound $\mathrm{O}_{2}$, since plasma and red blood cells are separated in such a manner that the inner vascular wall is covered with a plasma layer. During HV, the utilization of physically dissolved $\mathrm{O}_{2}$ is additionally favored due to the elevated gradient of $\mathrm{O}_{2}$ partial pressure to the interstitium $[11,12]$. The actual utilization of physically dissolved $\mathrm{O}_{2}$ is reflected by our data, as $\mathrm{HV}$ with pure $\mathrm{O}_{2}$ significantly increased the contribution of physically dissolved $\mathrm{O}_{2}$ to $\mathrm{DO}_{2}$ and $\mathrm{VO}_{2}$ (fig. $4 \mathrm{a}, \mathrm{b}$ ).

$\mathrm{HV}$ with $\mathrm{FiO}_{2} 1.0$ did not result in a substantially lower $\mathrm{Hb}_{\text {crit }}$ when compared to $\mathrm{FiO}_{2} 0.6$ (1.3 vs. $1.5 \mathrm{~g} / \mathrm{dl}$ ). However, the absolutely lowest values of $\mathrm{Hb}_{\text {crit }}$ were observed in 2 animals ventilated with $\mathrm{FiO}_{2}$ 1.0, which met $\mathrm{Hb}_{\text {crit }}$ at $0.8 \mathrm{~g} / \mathrm{dl}$. Moreover, a more extensive blood-forHES exchange was necessary for institution of $\mathrm{Hb}_{\text {crit }}$ than in animals ventilated with $\mathrm{FiO}_{2}$ 0.6.

$\mathrm{Hb}_{\text {crit }}$ marks the ultimate limit of anemia tolerance $[5,13]$; without further treatment (e.g. elevation of $\mathrm{FiO}_{2}$, transfusion of red blood cells or infusion of artificial $\mathrm{O}_{2}$ carriers), hemodilution to $\mathrm{Hb}_{\text {crit }}$ is associated with $100 \%$ mortality [14-16]. $\mathrm{Hb}_{\text {crit }}$ therefore reflects the limit of anemia tolerance at the level of the whole organism by averaging $\mathrm{VO}_{2}$ of all organs. However, this approach disregards the cellular and organ-specific level of anemia tolerance. A recent study investigated the limits of anemia tolerance of the heart, the brain, the kidneys, the liver, 
Pape et al.: The Limit of Anemia Tolerance during Hyperoxic Ventilation with Pure Oxygen in Anesthetized Domestic Pigs

Table 2. Hemodynamic and $\mathrm{O}_{2}$-derived parameters obtained in animals ventilated with ambient air (group 0.21 ) or with $\mathrm{FiO}_{2} 0.6$ (group 0.6)

\begin{tabular}{|c|c|c|c|c|}
\hline Parameter & Group & Baseline & $\mathrm{Hb}_{\text {crit }}-0.21$ & $\mathrm{Hb}_{\text {crit }}-0.6$ \\
\hline \multirow[t]{2}{*}{$\mathrm{Hb}, \mathrm{g} / \mathrm{dl}$} & 0.21 & $7.6 \pm 0.8$ & $2.4 \pm 0.5^{*}$ & \\
\hline & 0.6 & $8.2 \pm 0.7$ & $2.7 \pm 0.4^{*}$ & $1.6 \pm 0.4^{*}$ \\
\hline \multirow[t]{2}{*}{$\mathrm{HR}, \mathrm{l} / \mathrm{min}$} & 0.21 & $102 \pm 20$ & $138 \pm 27$ & \\
\hline & 0.6 & $100 \pm 13$ & $129 \pm 18$ & $110 \pm 35$ \\
\hline \multirow[t]{2}{*}{ MAP, mm Hg } & 0.21 & $98 \pm 18$ & $75 \pm 23$ & \\
\hline & 0.6 & $107 \pm 14$ & $92 \pm 23$ & $35 \pm 12^{*}$ \\
\hline \multirow{2}{*}{ MPAP, mm Hg } & 0.21 & $26 \pm 6$ & $22 \pm 4$ & \\
\hline & 0.6 & $16 \pm 5^{\S}$ & $15 \pm 7$ & $17 \pm 9$ \\
\hline \multirow[t]{2}{*}{$\mathrm{CI}, \mathrm{l} / \mathrm{min} / \mathrm{m}^{2}$} & 0.21 & $3.3 \pm 0.3$ & $5.4 \pm 1.1^{*}$ & \\
\hline & 0.6 & $3.5 \pm 0.6$ & $5.2 \pm 0.6^{*}$ & $3.7 \pm 1.7$ \\
\hline \multirow[t]{2}{*}{ SVI, $\mathrm{ml} / \mathrm{m}^{2}$} & 0.21 & $33 \pm 5$ & $39 \pm 5$ & \\
\hline & 0.6 & $35 \pm 7$ & $41 \pm 5$ & $34 \pm 12$ \\
\hline \multirow[t]{2}{*}{ SVRI, dyn•s $/ \mathrm{cm}^{5} / \mathrm{m}^{2}$} & 0.21 & $2,195 \pm 520$ & $929 \pm 235^{*}$ & \\
\hline & 0.6 & $2,452 \pm 380$ & $1,419 \pm 477^{*, \S}$ & $933 \pm 263$ \\
\hline \multirow[t]{2}{*}{ PVRI, dyn・s $/ \mathrm{cm}^{5} / \mathrm{m}^{2}$} & 0.21 & $246 \pm 229$ & $11 \pm 165$ & \\
\hline & 0.6 & $262 \pm 117$ & $157 \pm 96$ & $113 \pm 146$ \\
\hline \multirow[t]{2}{*}{$\mathrm{LVP}, \mathrm{mm} \mathrm{Hg}$} & 0.21 & $98 \pm 26$ & $83 \pm 29 *$ & \\
\hline & 0.6 & $121 \pm 24$ & $110 \pm 19$ & $60 \pm 15^{*}$ \\
\hline \multirow[t]{2}{*}{ LVEDP, mm Hg } & 0.21 & $11 \pm 7$ & $21 \pm 8$ & \\
\hline & 0.6 & $4 \pm 2^{\S}$ & $5 \pm 3^{*, \S}$ & $12 \pm 5^{*}$ \\
\hline \multirow[t]{2}{*}{$\mathrm{dp} / \mathrm{dt}_{\max }, \mathrm{mm} \mathrm{Hg} / \mathrm{s}$} & 0.21 & $2,011 \pm 1,132$ & $1,896 \pm 3,786^{\S}$ & \\
\hline & 0.6 & $2,698 \pm 1,554$ & $3,119 \pm 1,815$ & $1,790 \pm 741$ \\
\hline \multirow[t]{2}{*}{$\mathrm{dp} / \mathrm{dt}_{\min }, \mathrm{mm} \mathrm{Hg} / \mathrm{s}$} & 0.21 & $-2,817 \pm 1,176$ & $-2,568 \pm 1,299$ & \\
\hline & 0.6 & $-3,152 \pm 1,076$ & $-2,838 \pm 1,395$ & $-1,383 \pm 1,001$ \\
\hline \multirow[t]{2}{*}{$\mathrm{VO}_{2} \mathrm{I}, \mathrm{ml} / \mathrm{m}^{2} / \mathrm{min}$} & 0.21 & $190 \pm 40$ & $162 \pm 34$ & \\
\hline & 0.6 & $224 \pm 21$ & $215 \pm 21^{\S}$ & $150 \pm 46^{*}$ \\
\hline \multirow{2}{*}{$\mathrm{DO}_{2} \mathrm{I}, \mathrm{ml} / \mathrm{m}^{2} / \mathrm{min}$} & 0.21 & $331 \pm 43$ & $191 \pm 60 *$ & \\
\hline & 0.6 & $400 \pm 69$ & $231 \pm 44^{*}$ & $108 \pm 43^{*}$ \\
\hline \multirow[t]{2}{*}{$\mathrm{paO}_{2}, \mathrm{~mm} \mathrm{Hg}$} & 0.21 & $97 \pm 6$ & $116 \pm 16$ & \\
\hline & 0.6 & $272 \pm 21^{\S}$ & $279 \pm 26^{\S}$ & $279 \pm 46$ \\
\hline \multirow[t]{2}{*}{$\mathrm{CaO}_{2}, \mathrm{ml} / \mathrm{dl}$} & 0.21 & $10 \pm 1$ & $3.5 \pm 0.6^{*}$ & \\
\hline & 0.6 & $12 \pm 0.9^{\S}$ & $4.4 \pm 0.5^{*, \S}$ & $3.0 \pm 0.4^{*}$ \\
\hline \multirow[t]{2}{*}{$\mathrm{pvO}_{2}, \mathrm{~mm} \mathrm{Hg}$} & 0.21 & $32 \pm 4$ & $25 \pm 2 *$ & \\
\hline & 0.6 & $43 \pm 12^{\S}$ & $33 \pm 5^{\S}$ & $31 \pm 7$ \\
\hline \multirow[t]{2}{*}{$\mathrm{O}_{2} \mathrm{ER}, \%$} & 0.21 & $47 \pm 13$ & $50 \pm 13$ & \\
\hline & 0.6 & $40 \pm 11$ & $49 \pm 11$ & $52 \pm 14$ \\
\hline \multirow[t]{2}{*}{$\mathrm{pH}$} & 0.21 & $7.48 \pm 0.03$ & $7.43 \pm 0.05$ & \\
\hline & 0.6 & $7.35 \pm 0.03$ & $7.44 \pm 0.04$ & $7.38 \pm 0.08$ \\
\hline \multirow[t]{2}{*}{$\overline{\mathrm{BE}}, \mathrm{mmol} / \mathrm{l}$} & 0.21 & $3.8 \pm 1.4$ & $0.0 \pm 2.4$ & \\
\hline & 0.6 & $4.0 \pm 1.3$ & $2.4 \pm 1.5$ & $-2.1 \pm 2.7$ \\
\hline \multirow[t]{2}{*}{ Lactate, $\mathrm{mmol} / \mathrm{l}$} & 0.21 & $2.2 \pm 1.1$ & $2.8 \pm 1.3$ & \\
\hline & 0.6 & $1.2 \pm 0.4$ & $1.1 \pm 0.4^{\S}$ & $3.2 \pm 1.4^{*}$ \\
\hline $\mathrm{CPP}, \mathrm{mm} \mathrm{Hg}$ & 0.21 & $69 \pm 15$ & $39 \pm 23$ & \\
\hline & 0.6 & $81 \pm 13$ & $56 \pm 15^{\S}$ & $10 \pm 10^{*}$ \\
\hline LAD flow, $\mathrm{ml} / \mathrm{min}$ & 0.21 & $54 \pm 15$ & $181 \pm 65^{*}$ & \\
\hline & 0.6 & $47 \pm 20$ & $138 \pm 100^{*}$ & $99 \pm 44$ \\
\hline $\mathrm{mDO}_{2}, \mathrm{ml} / \mathrm{min}$ & 0.21 & $540 \pm 155$ & $634 \pm 259$ & \\
\hline & 0.6 & $541 \pm 209$ & $622 \pm 478$ & $309 \pm 149$ \\
\hline cv lactate, $\mathrm{mmol} / \mathrm{l}$ & 0.21 & $1.8 \pm 0.8$ & $2.8 \pm 1.7^{*}$ & \\
\hline & 0.6 & $0.7 \pm 0.2$ & & $4.2 \pm 1.9 *$ \\
\hline
\end{tabular}

Data excerpted from our previous study [7]. For abbreviations, see text and table $1 .{ }^{*} \mathrm{p}<0.05$ vs. baseline; $\S \mathrm{p}<0.05$ vs. group 0.21 . 
Pape et al.: The Limit of Anemia Tolerance during Hyperoxic Ventilation with Pure Oxygen in Anesthetized Domestic Pigs

the small intestine and the skeletal muscle. Especially in the kidneys and in the skeletal muscle, signs of tissue hypoxia were observed before the critical limit of systemic $\mathrm{O}_{2}$ supply was reached [17].

Although neglecting the organ-specific level of anemia tolerance may be judged as a limitation of the present experimental model, the assessment of total-body $\mathrm{Hb}_{\text {crit }}$ has been used in several experimental hemodilution studies. In particular, a reduction of $\mathrm{Hb}_{\text {crit }}$ could be achieved by hypothermia (moderate reduction of body core temperature reduces total body $\mathrm{O}_{2}$ demand [18]), infusion of norepinephrine (stabilization of CPP during hemodilution [19]), infusion of artificial $\mathrm{O}_{2}$ carriers (maintenance of $\mathrm{CaO}_{2}$ despite reduced hematocrit $[20,21]$ ) and continuous NMB (lowering skeletal muscular $\mathrm{O}_{2}$ demand [22]).

Notably, in paralyzed animals, $\mathrm{Hb}_{\text {crit }}$ was found about $1 \mathrm{~g} / \mathrm{dl}$ lower than in animals without NMB. NMB was used in the present study as well as in our previous study [7] to eliminate muscular activity and thereby to enable exact performance of tpO $\mathrm{O}_{2}$ measurement.

Moreover, the choice of the infusion fluid used for hemodilution has an impact on $\mathrm{Hb}_{\text {crit }}$. While the use of HES in the clinical setting is presently a matter of controversy, mid-molecular HES preparations have at least in the experimental setting proven effective regarding the maintenance of tissue oxygenation in profound anemia and were in this respect superior to gelatin or to crystalloids [23]. The advantages of HES 130/0.4 were explained with a lower degree of extravasation resulting in a more sustained volume effect and reduced tissue edema formation.

Hemodilution and hyperoxia have antipodal effects on microvascular resistance. Accelerated blood flow increases shear stress at the endothelial vascular layer, resulting in the release of nitrous oxide and vasodilation $[24,25]$. These effects are, however, counteracted by hyperoxic vasoconstriction, which has been observed in large vessels as well as in microvessels (arterioles, venules) [26, 27]. While these effects are balanced at moderate degrees of anemia, stages of profound anemia are characterized by hypotension. When blood viscosity and, thus, intracapillary blood pressure fall below the hydrostatic pressure of the capillary-surrounding tissue, microvascular collapse is imminent $[28,29]$.

In the present study, microvascular collapse is indicated by the extreme left shift of the $\mathrm{tpO}_{2}$ histograms, which occurred despite the significant portion of physically dissolved $\mathrm{O}_{2}$ to $\mathrm{O}_{2}$ supply. Impaired microvascular perfusion is also reflected by global indicators of tissue hypoxia (decreasing base excess and $\mathrm{pH}$, increasing lactate concentration). As single organs have not been investigated in the present study, it is neither possible to localize potential origins of lactate production, nor to distinguish the degree of tissue hypoxia within particular organs.

Moreover, at their individual $\mathrm{Hb}_{\text {crit }}$ animals subjected to $\mathrm{HV}$ were more hypotensive than animals ventilated with ambient air. At extremely low $\mathrm{Hb}$ concentrations, myocardial oxygenation became compromised by anemic hypoxia as well as by decreasing CPP. As a consequence, cardiac output declines, resulting in a decrease of coronary blood flow and a further limitation of myocardial perfusion.

The onset of this vicious circle not only accelerates the breakdown of hemodynamic compensation, thereby directly decreasing $\mathrm{VO}_{2}$. This implies that at extremely low Hb levels, the primary endpoint of the experimental protocol is influenced by effects beyond limited $\mathrm{O}_{2}$ transport capacity, which should be judged as a weakness of our experimental model. However, at $\mathrm{Hb}_{\text {crit }}-0.21, \mathrm{VO}_{2}$ was obviously not affected by circulatory failure, so that our main conclusion remains applicable, namely that $\mathrm{HV}$ with either $\mathrm{FiO}_{2}$ increased anemia tolerance and therefore enabled continuation of hemodilution to $\mathrm{Hb}$ values below $2.4 \mathrm{~g} / \mathrm{dl}$ (i.e. $\mathrm{Hb}_{\text {crit }}{ }^{-}$ 0.21 ).

The present study was motivated by the fact that in our previous study, $\mathrm{FiO}_{2}$ had to be restricted to 0.6 for methodological reasons; the endpoint of the hemodilution protocol (i.e. 
the onset of $\mathrm{O}_{2}$ supply dependency of $\mathrm{VO}_{2}$ ) was assessed with a Deltatrac ${ }^{\mathrm{TM}}$ II metabolic monitor (Datex-Engström, Helsinki, Finland) [7]. This device calculates $\mathrm{VO}_{2}$ as the quotient of $\mathrm{CO}_{2}$ production $\left(\mathrm{VCO}_{2}\right)$ and the respiratory quotient (RQ), the latter being calculated with the Haldane transformation (see Appendix). As this algorithm yields implausible results when $\mathrm{FiO}_{2}$ exceeds a maximum of 0.65 , the institution of $\mathrm{FiO}_{2} 1.0$ is impossible using the Deltatrac II metabolic monitor [30]. Therefore, the question remained open whether a further increase of $\mathrm{FiO}_{2}$ from 0.6 to 1.0 would additionally increase the tolerance of acute normovolemic anemia.

At a later time point, the Oxycon Pro device became available. The algorithm of this device is based on the measurement of expiratory $\mathrm{O}_{2}$ and $\mathrm{CO}_{2}$ fractions with a paramagnetic and an infrared absorption sensor, respectively. According to the manual, the accuracy of measurement is $3 \%$ or $0.05 \mathrm{l} / \mathrm{min}$, respectively. However, the Oxycon Pro device exerts a modified Haldane transformation, which allows assessment of $\mathrm{VO}_{2}$ even during $\mathrm{HV}$ with pure oxygen, providing that the system has been calibrated with $\mathrm{FiO}_{2}$ 1.0. Although this algorithm underwent an in-house validation by the manufacturer, it has neither been published in detail so far, nor has it been validated against other techniques (e.g. reverse Fick principle). While the validity and reliability of $\mathrm{VO}_{2}$ assessment with the Oxycon Pro device has already been investigated under normoxic conditions [31], this device was used in a recently published study investigating the effects of $\mathrm{HV}\left(\mathrm{FiO}_{2} 1.0\right)$ on $\mathrm{VO}_{2}$ and $\mathrm{RQ}$ in healthy spontaneously breathing volunteers [32].

In the setting of experimental hemodilution, the Oxycon Pro device enabled us for the first time to assess $\mathrm{VO}_{2}$ even during $\mathrm{HV}$ with pure oxygen. With respect to the number of experimental animals and for ethical reasons, we decided to only perform the present 7 experiments and to use the results of the previous study in terms of 2 historical reference groups.

Our data demonstrate that $\mathrm{HV}$ with pure $\mathrm{O}_{2}$ only provides a marginal gain of anemia tolerance as compared with $\mathrm{FiO}_{2}$ 0.6. Overall, the extensive blood-for-HES exchange until the onset of $\mathrm{O}_{2}$ supply dependency implies that $\mathrm{HV}$ allows to delay the transfusion of red blood cells, e.g. in case of bridging an acute blood loss until blood products become available. However, while the lack of $\mathrm{O}_{2}$ carriers can be compensated by physically dissolved $\mathrm{O}_{2}$ in extreme anemia (i.e. Hb concentrations $<2 \mathrm{~g} / \mathrm{dl}$ ), $\mathrm{O}_{2}$ transport becomes additionally impaired by cardiovascular collapse and microvascular perfusion disorders. Despite the excellent bioavailability of physically dissolved $\mathrm{O}_{2}$, the management of extreme normovolemic anemia might require a multimodal approach including the choice of the optimal infusion fluid, deep $\mathrm{NMB}$ and circulatory support with catecholamines [1]. HV with $\mathrm{FiO}_{2} 1.0$ might temporarily be useful; however, $\mathrm{HV}$ with $\mathrm{FiO}_{2} 0.6$ has equipotent effects on maintaining $\mathrm{O}_{2}$ supply to the tissues.

\section{Acknowledgements}

The authors very much appreciate Mr. Ahmed Haroun's valuable technical assistance and A. Theisen's (DVM), M. Wagenblast's (DVM) and their team's excellent performance in animal care.

\section{Disclosure Statement}

The study was in part sponsored by Terumo Inc., Kanagawa, Japan. The Oxycon Pro device was provided by Viasys Healthcare. The authors have no financial interests to disclose. 


\section{Appendix}

Body surface area (BSA) was calculated according to Holt et al. [33]:

$B S A=k \cdot B W^{2 / 3}\left(\mathrm{~m}^{2}\right)$,

where BW = body weight (in kg) and $\mathrm{k}=9$ (constant for the species pig).

CI was calculated as:

$$
C I=\frac{C O}{B S A}\left(\frac{l}{\mathrm{~m}^{2}}\right),
$$

where $\mathrm{CO}=$ cardiac output.

Stroke volume index (SVI) was calculated as:

$$
S V I=\frac{C I}{H R}\left(\frac{l}{\mathrm{~m}^{2}}\right),
$$

where $\mathrm{HR}=$ heart rate.

SVRI and PVRI were calculated as:

$$
S V R I=\frac{(M A P-C V P) \cdot 79.9}{C I}\left(\frac{\mathrm{dyn} \cdot \mathrm{s}}{\mathrm{cm}^{5} \cdot \mathrm{m}^{2}}\right) \text { and } P V R I=\frac{(M P A P-L V E D P) \cdot 79.9}{C I}\left(\frac{\mathrm{dyn} \cdot \mathrm{s}}{\mathrm{cm}^{5} \cdot \mathrm{m}^{2}}\right) \text {, }
$$

respectively, where MAP = mean aortic pressure; $\mathrm{CVP}$ = central venous pressure; MPAP = mean pulmonary arterial pressure, and LVEDP = left ventricular end-diastolic pressure.

$\mathrm{O}_{2}$ ER was calculated as follows:

$$
\mathrm{O}_{2} \mathrm{ER}=\frac{\mathrm{CaO}_{2}-\mathrm{CvO}_{2}}{\mathrm{CaO}_{2}} \cdot 100(\%),
$$

where $\mathrm{CaO}_{2}$ and $\mathrm{CvO}_{2}$ are arterial and mixed venous $\mathrm{O}_{2}$ content.

The contribution of physically dissolved $\mathrm{O}_{2}$ ( physO $_{2}$ ) to $\mathrm{DO}_{2}$ and to $\mathrm{VO}_{2}$ was calculated as:

$$
p y \mathrm{~S}_{2} / \mathrm{DO}_{2}=\frac{0.0031 \cdot \mathrm{paO}_{2}}{\mathrm{CaO}} \cdot 100(\%) \text { and } p h y s \mathrm{O}_{2} / \mathrm{VO}_{2}=\frac{\left(0.0031 \cdot \mathrm{paO}_{2}-0.0031 \cdot \mathrm{pvO}_{2}\right) \cdot 10}{\mathrm{CaO}_{2}-\mathrm{CvO} \mathrm{O}_{2}} \cdot 100(\%) \text {, }
$$

respectively, where $\mathrm{paO}_{2}=$ arterial oxygen partial pressure.

CPP was calculated as:

$C P P=D A P-L V E D P$,

where $\mathrm{DAP}=$ diastolic aortic pressure.

Myocardial $\mathrm{DO}_{2}\left(\mathrm{mDO}_{2}\right)$ and myocardial $\mathrm{VO}_{2}\left(\mathrm{mVO}_{2}\right)$ were calculated for the LAD-supplied area:

$$
\begin{aligned}
& \mathrm{mDO}_{2}=\mathrm{LAD} \cdot \mathrm{CaO}_{2} \\
& \mathrm{mVO}_{2}=\mathrm{LAD} \cdot\left(\mathrm{CaO}_{2}-\mathrm{CcVO}_{2}\right),
\end{aligned}
$$

where $\mathrm{LAD}=\mathrm{LAD}$ blood flow.

For the same myocardial area, myocardial $\mathrm{O}_{2} \mathrm{ER}\left(\mathrm{mO}_{2} \mathrm{ER}\right)$ ratio was calculated as:

$$
\mathrm{mO}_{2} \mathrm{ER}=\frac{\mathrm{CaO}_{2}-\mathrm{CcvO}}{\mathrm{CaO}_{2}} \cdot 100(\%) \text {. }
$$

For calculation of $\mathrm{VO}_{2}, \mathrm{CO}_{2}$ production $\left(\mathrm{VCO}_{2}\right)$ is divided by the $\mathrm{RQ}$, which is calculated by the Haldane transformation:

$$
\begin{aligned}
& \text { (1) } \mathrm{VO}_{2}=\frac{\mathrm{VCO}_{2}}{R Q} \\
& \text { (2) } \mathrm{RQ}=\frac{1-\mathrm{FiO}_{2}}{\frac{\mathrm{FiO}_{2}-\mathrm{FeO}_{2}}{\mathrm{FeCO}_{2}}-\mathrm{FiO}_{2}},
\end{aligned}
$$

where $\mathrm{FeO}_{2}=$ expiratory $\mathrm{O}_{2}$ fraction and $\mathrm{FeCO}_{2}=$ expiratory $\mathrm{CO}_{2}$ fraction.

For induction and maintenance of anesthesia, the following drugs were used: ketamine (Ketavet ${ }^{\mathrm{TM}}$, Parke-Davis, Berlin, Germany); midazolam (Midazolam ${ }^{\mathrm{TM}}$, Ratiopharm, Ulm, Germany); propofol (Brevimytal $^{\mathrm{TM}}$, Braun, Bad Melsungen, Germany); fentanyl (Fentanyl ${ }^{\mathrm{TM}}$, Janssen, Neuss, Germany); pancuronium (Pancuronium $^{\mathrm{TM}}$, Curamed, Karlsruhe, Germany); balanced electrolyte solution (Tutofusin ${ }^{\mathrm{TM}}$, Pharmacia, Erlangen, Germany), and HES 130/0.4 (Voluven ${ }^{\mathrm{TM}}$, Fresenius Kabi, Bad Homburg, Germany). 
Pape et al.: The Limit of Anemia Tolerance during Hyperoxic Ventilation with Pure Oxygen in Anesthetized Domestic Pigs

\section{References}

- 1 Pape A, Habler 0: Alternatives to allogeneic blood transfusions. Best Pract Res Clin Anaesthesiol 2007;21: 221-239.

- 2 Messmer KF: Acceptable hematocrit levels in surgical patients. World J Surg 1987;11:41-46.

3 Habler OP, Messmer KF: The physiology of oxygen transport. Transfus Sci 1997;18:425-435.

- 4 Madjdpour C, Spahn DR, Weiskopf RB: Anemia and perioperative red blood cell transfusion: a matter of tolerance. Crit Care Med 2006;34:S102-S108.

- 5 Cain SM: Oxygen delivery and uptake in dogs during anemic and hypoxic hypoxia. J Appl Physiol 1977;42: 228-234.

- 6 Schumacker PT, Cain SM: The concept of a critical oxygen delivery. Intensive Care Med 1987;13:223-229.

7 Pape A, Meier J, Kertscho H, Steche M, Laout M, Schwerdel F, Wedel M, Zwissler B, Habler OP: Hyperoxic ventilation increases the tolerance of acute normovolemic anemia in anesthetized pigs. Crit Care Med 2006;34: 1475-1482.

- 8 Meier JM, Woelkhammer S, Habler OP: The Deltacrit-System (DCS) - a new method for online-determination of critical $\mathrm{VO}_{2}$-decline. Comput Biol Med 2003;33:395-405.

- 9 Haller M, Akbulut C, Brechtelsbauer H, Fett W, Briegel J, Finsterer U, Peter K: Determination of plasma volume with indocyanine green in man. Life Sci 1993;53:1597-1604.

10 Kessler M, Hoper J, Krumme BA: Monitoring of tissue perfusion and cellular function. Anesthesiology 1976; 45:184-197.

11 Pittman RN: Oxygen supply to contracting skeletal muscle at the microcirculatory level: diffusion vs convection. Acta Physiol Scand 2000;168:593-602.

12 Wettstein R, Tsai AG, Erni D, Lukyanov AN, Torchilin VP, Intaglietta M: Improving microcirculation is more effective than substitution of red blood cells to correct metabolic disorder in experimental hemorrhagic shock. Shock 2004;21:235-240.

13 De Backer D: V02/D02 relationship: how to get rid of methodological pitfalls? Intensive Care Med 2000;26: 1719-1722.

14 Meier JM, Kemming GI, Kisch-Wedel H, Wolkhammer S, Habler OP: Hyperoxic ventilation reduces 6-hour mortality at the critical hemoglobin concentration. Anesthesiology 2004;100:70-76.

$\checkmark 15$ Meier JM, Pape A, Lauscher P, Zwissler B, Habler OP: Hyperoxia in lethal methemoglobinemia - effects on $\mathrm{O}_{2}$ transport, tissue oxygenation and survival in pigs. Crit Care Med 2005;33:1582-1588.

16 Pape A, Kertscho H, Meier J, Horn O, Laout M, Steche M, Lossen M, Theisen A, Zwissler B, Habler O: Improved short-term survival with polyethylene glycol modified hemoglobin liposomes in critical normovolemic anemia. Intensive Care Med 2008;34:1534-1543.

-17 Lauscher P, Kertscho H, Schmidt O, Zimmermann R, Rosenberger P, Zacharowski K, Meier J: Determination of organ-specific anemia tolerance. Crit Care Med 2013;41:1037-1045.

-18 Perez-de-Sa V, Roscher R, Cunha-Goncalves D, Larsson A, Werner O: Mild hypothermia has minimal effects on the tolerance to severe progressive normovolemic anemia in Swine. Anesthesiology 2002;97:1189-1197.

19 Meier J, Pape A, Loniewska D, Lauscher P, Kertscho H, Zwissler B, Habler O: Norepinephrine increases tolerance to acute anemia. Crit Care Med 2007;35:1484-1492.

20 Habler OP, Kleen MS, Hutter JW, Podtschaske AH, Tiede M, Kemming GI, Welte MV, Corso CO, Batra S, Keipert PE, Faithfull NS, Messmer KF: Hemodilution and intravenous perflubron emulsion as an alternative to blood transfusion: effects on tissue oxygenation during profound hemodilution in anesthetized dogs. Transfusion 1998;38:145-155.

21 Meisner FG, Kemming GI, Habler OP, Kleen MS, Tillmanns JH, Hutter JW, Bottino DA, Thein E, Meier JM, Wojtczyk CJ, Pape A, Messmer KF: Diaspirin crosslinked hemoglobin enables extreme hemodilution beyond the critical hematocrit. Crit Care Med 2001;29:829-838.

-22 Pape A, Kertscho H, Stein P, Lossen M, Horn O, Kutschker S, Zwissler B, Habler O: Neuromuscular blockade with rocuronium bromide increases the tolerance of acute normovolemic anemia in anesthetized pigs. Eur Surg Res 2011;48:16-25.

23 Pape A, Kutschker S, Kertscho H, Stein P, Horn O, Lossen M, Zwissler B, Habler O: The choice of the intravenous fluid influences the tolerance of acute normovolemic anemia in anesthetized domestic pigs. Crit Care 2012; 16:R69.

24 Dimmeler S, Fleming I, Fisslthaler B, Hermann C, Busse R, Zeiher AM: Activation of nitric oxide synthase in endothelial cells by Akt-dependent phosphorylation. Nature 1999;399:601-605.

-25 Doss DN, Estafanous FG, Ferrario CM, Brum JM, Murray PA: Mechanism of systemic vasodilation during normovolemic hemodilution. Anesth Analg 1995;81:30-34.

26 Habler OP, Kleen MS, Kemming GI, Zwissler B: Hyperoxia in extreme hemodilution. Eur Surg Res 2002;34: 181-187.

27 Habler OP, Messmer KF: Hyperoxaemia in extreme haemodilution. Br J Anaesth 1998;81(suppl 1):79-82.

28 Mazzoni MC, Tsai AG, Intaglietta M: Blood and plasma viscosity and microvascular function in hemodilution. A perspective from La Jolla, California. Eur Surg Res 2002;34:101-105. 
Pape et al.: The Limit of Anemia Tolerance during Hyperoxic Ventilation with Pure Oxygen in Anesthetized Domestic Pigs

-29 Cabrales P, Intaglietta M, Tsai AG: Transfusion restores blood viscosity and reinstates microvascular conditions from hemorrhagic shock independent of oxygen carrying capacity. Resuscitation 2007;75:124-134.

30 Merilainen PT: Metabolic monitor. Int J Clin Monit Comput 1987;4:167-177.

31 Carter J, Jeukendrup AE: Validity and reliability of three commercially available breath-by-breath respiratory systems. Eur J Appl Physiol 2002;86:435-441.

-32 Lauscher P, Lauscher S, Kertscho H, Habler O, Meier J: Hyperoxia reversibly alters oxygen consumption and metabolism. ScientificWorldJournal 2012;2012:410321.

-33 Holt JP, Rhode EA, Kines H: Ventricular volumes and body weight in mammals. Am J Physiol 1968;215:704715. 